\title{
Sickness and Healing in the Old Testament and Pentecostalism: Then and Now
}

\section{Fairchild Siyawamwaya}

\begin{abstract}
Sickness and healing have been with humanity since time immemorial. Although there are few cases of healings in the Old Testament, the healings in the Old Testament correctly provides a mirror through which healings in Pentecostalism can be interrogated. The article therefore explored selective cases of sickness and cure in the Old Testament and juxtaposes the same phenomena in Pentecostalism today. The phenomenological approach, historical critical method, exegesis and typological comparative analysis were used to gather data for this qualitative research. The findings are that most cures in the Old Testament portray the undisputed role of the divine. On the contrary, cures in Pentecostalism have been viewed with mixed feelings stemming from the fraudulent behaviour of healing practitioners today. Nonetheless, most believers are still gullible enough to believe it. The article employs religious fundamentalism as a theoretical framework and argues that faith healing cannot be accepted at face value, as it has seen its sad manifestation in unwarranted behaviour.
\end{abstract}

Keywords: sickness, healing, Old Testament, Pentecostalism, gullible.

\section{Introduction}

The Pentecostal explosion in Zimbabwe has brought a lot of beleaguering phenomena that have been subject to scholarly permutations. A deluge of works has examined the salient features of Pentecostalism that include prosperity gospel, prophecy, healing and exorcism, among others. Biri (2012) examined the aspect of healing but did not manage to expound on the possible Old Testament influence on Pentecostals' understanding of healing. Similarly, 
Taringa (2013) expounds on the influence of African Traditional Religion (ATR) on Pentecostals, but his study is devoid of the flair of the Old Testament Tradition.

The study sought to unravel the aspect of sickness and healing in Zimbabwean Pentecostalism, taking a cue from the Old Testament perspective. The article commences by unpacking the methodological considerations used. The article then looks at fundamentalism as a philosophy guiding it. The article proceeds from looking at sickness and healing in the Old Testament biblical culture. After that, the article examined the perceptions on sickness and healing in Pentecostalism today. It therefore analyses the methods of healing in Pentecostalism considering chronic illnesses. The article argues that while others have benefited from faith healing, this phenomenon cannot be eulogised, as it has unwittingly resulted in unwarranted deaths. The article concludes that faith healing devoid of medical verification is tantamount to dishonesty.

\section{Methodology}

The study employs a poly-methodical approach cognisant of Pummers' (1975) word of caution that no single methodology can lead to an all-encompassing understanding of religious phenomena. This stems from the fact that a single approach to the study of a beleaguered phenomenon like Pentecostalism will suffer from reductionism. Consequently, many aspects will escape attention. Therefore, the researcher found it prudent to understand the phenomenon of healing in Zimbabwean Pentecostalism through multiple lenses.

Firstly, the phenomenological approach was instrumental in this research. The article is aware of the complex nature of defining phenomenology, as it has been argued by scholars that there are many phenomenologists. However, to go into a lengthy discussion on the diversity of phenomenology would be beyond the scope of this discussion. As Edmund Husserl (1859-1938) notes, phenomenology of religion is centred on three concepts, namely epoche, empathy and eidetic intuition. Etymologically, epoche comes from the Greek word epecho, which means 'I hold back'. This entails that a scholar or researcher must undertake his or her research without preconceived ideas or notions on already known values of the subject under research. Eidetic intuition, which is also called eidetic vision, is a search for or a look into the essentials of religious phenomena. This includes describing relationships and processes. Such processes in Zimbabwean Pentecostalism include the concept 
of healing, how it could have been borrowed from African spirituality and why it has even become one of the pull factors. Mapuranga, Chitando and Gunda (2013) argue that the phenomenological method seeks to undertake a balanced and unbiased research.

Pentecostalism as a movement also needs to be interrogated from a biblical studies perspective. The goal would be to understand the exegetical and hermeneutical considerations that inspire the use of the texts in these movements. This emanates from the fact that as scholars there is a need for an understanding of the readings used in these movements, as opposed to readings that scholars might use. In most instances, the reading of the Bible in these churches has been subject to scholarly permutations.

\section{Historical-critical Method}

According to Hayes and Holladay (2007), historical criticism of documents assumes that a text is historical in at least two senses: it may relate to history, as well as have its own history. For this reason, we can distinguish between 'the history in the text' and 'the history of the text'. In this sense the text may serve as a window through which we can peep into the historical period (Hayes \& Holladay 2007). This method is very useful for the subject under investigation, since it deals with matters pertaining to the history in the text, or situates matters pertaining to the history in the text, or the situation the text describes. If the text contains references to places, persons and customs strange to the reader it will be necessary to become sufficiently acquainted with the historical period or the cultural setting described in the text in order to understand what is being said at the most elementary level (Hayes \& Holladay 2007).

The historical critical method includes the presupposition that history is a unit in the sense of a closed continuum of effects in which an individual event is connected by a succession of causes and effects. This method involves careful analytical study and an evaluation of records and accounts of historical events and developments (Hayes \& Holladay 2007). This article employs this method as it investigates the past to observe what is essential and mainstream, to the contemporary demanding interpretation. The biblical Old Testament sickness and healing stories have been interpreted through African eyes, taking into cognisance this method (Hayes \& Holladay 2007). 


\section{The Comparative Method}

The method generally strives to compare different tendencies or different aspects. The method identifies differences and similarities from among a mixed bag of variants. The two contexts here are to be compared and contrasted, and so are the causes and cure of diseases in the Old Testament bible culture and in Zimbabwean Pentecostalism. Thus, the essentiality of this method in this study cannot be trivialised.

\section{Limitations of the Methods}

There are limitations in the methodology that has been used. Reality is so rich and manifold that no single rationalisation is able to capture it. Hence, in order to minimise the limitations of using one approach, these approaches have been employed. Even though it is difficult to penetrate a historicised religious community, which one seeks to study, as from the Old Testament, this is exacerbated due to barriers of culture and language. Admittedly, the research findings are not free from presuppositions and value judgments, even though the methods used have reduced them to some degree.

\section{Theoretical Framework}

This article adopts religious fundamentalism as a working philosophy to underpin it. The study is aware of the ambiguous nature of the term 'religious fundamentalism', which has been understood from various perspectives. Nevertheless, this study is greatly indebted to Taringa (2013), who made an attempt to unpack the term both from a historical and ideological level. This is a testimony to the position that the term defies a single definition. Taringa (2013), citing Sacks (2000), argue that from a historical vantage point, the word was coined in America in the 1920s in the wake of a series of pamphlets setting out the fundamentals of Christian belief. At its simplest level it is just that kind of common-sense defence of Orthodoxy in a highly secular age; a reaction against what is seen as liberal intelligentsia's subversion of established beliefs. Taringa also brings to the fore the manifestation of the philosophy of fundamentalism. Taringa (2013) cites Armstrong on the pattern of fundamentalists. They are embattled forms of spirituality that have emerged in response to perceived crisis. They are engaged in conflict with enemies whose secularist policies and beliefs seem inimical to religion. Fundamentalists do 
not regard this battle as a conventional political struggle, but experience it as a cosmic war between the forces of good and evil. They fear annihilation and try to fortify their beleaguered identity by means of a selective retrieval of certain doctrines. It is against the backdrop of the proffered definition that the study argues that faith healers are fundamentalists.

\section{Sickness and Healing in the Old Testament Biblical Culture The Moral Causes of Illness}

In the Old Testament tradition, some sicknesses were epitomised to be the result of divine punishment and this may be caused by various reasons. In Old Testament times, the general understanding was that God has given human beings a system or code of conduct, which he oversees through reward and punishment. The impression that is therefore created is that sickness is a result of divine punishment. The moment sickness is epitomised as divine punishment it means that it is tinged with an individual's morality.

In ancient Israel, it was thought that sickness was a divine instrument to punish a wayward, stubborn individual, or it was used to provide an example for faith as in the case of the biblical Job (Vess et al. 2009). The story of Job helps to bring to the fore the notion that in Hebraic thought immorality could cause sickness. Nevertheless, contemporary believers use the story of Job to provide an example of faith. Kinsley (1994) adds something very fundamental towards an understanding of sickness because of divine punishment, and this is inextricably embedded in the Deuteronomist philosophy. ${ }^{1}$ It is the Deuteronomist philosophy that sin brings sickness, whilst righteousness is tantamount to prosperity and good health. It syllogistically follows that when the sickness is attributed to the divine, the individual would be responsible for that sickness.

It should be borne in mind that the Deuteronomist philosophy on sin has been a cause of disagreement in scholarly debate. This is buttressed by the fact that such an understanding of sickness as a curse was theologically and ideologically motivated. Considering ideological conception as seen in the works of Giovanni Garbinni (1988), this research would argue that the

1 The Deuteronomist philosophy is part of a theology of legitimising philosophy that justifies the status quo as unwittingly, poverty was depicted as a result of a curse and riches and health as ramifications of blessings from Yahweh. 
Deuteronomist philosophy is a scheme by the elites in ancient Israel who wanted to blind the ordinary people from reality. This was the result of an ideology clandestinely orchestrated in diabolical gusto as unwittingly, uncritical citizens accepted their sickness and suffering to be a result of God's discontentment of their deeds. This was a position that need not only be dismissed but also rather be dismissed with scorn.

\section{Ritual Impurity as Cause of Illness}

The Levitical legislation ${ }^{2}$ reduces the fear of the unknown or hostile unclean power to a matter of God's law. Uncleanness is hateful to God and must be avoided by all who have to do with divinity. All the biblical views of purity and impurity represent a realisation of taboos by the attribution of such matters to the divine will. Here the decision about what is impure is entirely up to YHWH alone and subjective, divine judgment is not questioned. This view does not explain why something is to be considered taboo or not.

Jonathan Klawans (2000) in his book, Impurity and Sin in ancient Judaism, proffers insights on ritual impurity that has been perceived instructively in this study. His view is largely based on Jacob Milgrom (2004) and contends that ritual impurity is caused by a physical condition and contact with other impure objects such as a corpse (as contained in Lev 11-15; Numbers 19). In her book, Gentile Impurities and Jewish identities: Intermarriage Conversion from the Bible to the Talmud (2002), Christian Hayes advocates a similar view, but distinguishes three forms of impurity. She agrees with Klawans in the sense that cultic impurity is contact with dead animals, sexual fluids, certain skin diseases, and the like. It can normally be removed (through skin turmah) or can be permanent after a set of intervals through procedures also laid down in the text. Contact between the sacred and the turmah creates a profound taboo and could produce a terrible result for the guilty party in particular and the community as a whole.

Within the Israelite community, purity laws were largely applied to physical conditions seen as impeding the community with YHWH. Common examples are the non-admittance of disabled priests in the temple (Lev 21) and

${ }^{2}$ A rational system of theological thought expounded in the book of Leviticus, which contains moral precepts and some of the laws concerning the Temple ritual and construction. 
the diagnosis of King Uzzah (1 Kings). He was to be isolated from the rest of the people, yet he was allowed to retain his kingship.

Ritual not permitted is distinguished by the following features: first, it is contagious, transferred from one person or object to another in a variety of way such as physical contact or sharing space within a covered area. Secondly, impurity emanating from a source of ritual impurity is impermanent and can be reduced and removed by some combinations of ablutions; time and/or performance of specified rituals. Thirdly, ritual impurity can defile sancta and must be kept separate from other persons. More severe forms of ritual impurity can also defile common objects and would thus require isolation.

Leprosy is a conventional, but erroneous rendering of the Hebrew Zara' at. The term covers a set of skin lesions in humans that feature scaling of the skin as well as fungal growth in clothes and residential buildings; these are detailed in Lev 13-14. Skin lesions of humans generate a most severe impurity (defiling of both sancta) and can be subdivided as follows: one type is immediately declared as impure; another as pure (including a case where even the symptom appears on the whole body). A third type requires isolation for a week or a fortnight and if there is no deterioration, the bearer is considered pure (Freilich 1982). It is against this backdrop that the scale-diseased person can defile even common objects and persons. Therefore, he is either restricted or excluded from the community (Lev 13: 46; Numbers 12:14-15). The purification ritual is carried out by the priests after healing is complete (hence the ritual is not curative). It is more intricate and complicated unlike other impure persons and bears certain similarities to the Hazazel (scapegoat) ceremony on the Day of Atonement (Lev 16: 5). Impurity is removed by sprinkling the mixture of bird blood and water and the impurity is then carried away by the live bird. The person bathes, launders and shaves, waits a week, and then bathes, launders and shaves again before offering a special sacrifice at the sanctuary. Houses from which Zara' at has been removed are purified by sprinkling and dispatching of the bird. Fabrics are purified by washing.

\section{Physical Causes of Illness}

This section deals with the physical causes of illness and for the purpose of demonstration has deliberately chosen selective biblical characters to discuss their possible neurological diseases. Firstly, the article shall refer to Isaac. The first clear allusion to Isaac's infirmities is seen in Genesis 27: 1, 'and it comes 
to pass that when Isaac was old and his eyes were dim that he could not see'. Further reading of the chapter brings to light the incident when Isaac could not distinguish between his sons, Jacob and Esau by the feel of their skin (although the former was disguised). This leads one to suspect that Isaac suffered from sensory neuropathy, as he was unable to feel the difference between human skin and animal skin. It has been speculated that Isaac was diabetic. Isaac and his father Abraham had the same plight of premature aging. Isaac needed a constant supply of water. Genesis 26 shows that his servants were constantly digging for water whenever they moved off. Isaac had noteworthy physical achievements noted in the Bible. He was fond of food, suffered visual loss and was impotent (he and his wife bore Jacob and Esau only after 20 years). It is possible that autonomic neurotherapy results from diabetes. All these points shed light to the premise that Isaac suffered from diabetes from the onset. He is one of the first recorded cases of diabetes in the Bible tradition.

Secondly, Genesis 32:25 provides a description of Jacob's duel with God (who appeared in the form of an angel). Jacob had camped overnight at a place that came to be known as Peniel after having sent his family and friends ahead of him, when the angel wrestled with Jacob till daybreak. The angel could not overpower Jacob and consequently. It is against this background that the angel had to take the hollow of his thighs. At that juncture the hollow of Jacob's thigh was out of joint. This could have been a posterior dislocation severe enough to change the sciatic nerve. If such were the case, the disruption could have disrupted the blood supply.

\section{Healing by Forgiveness of Sins}

It is noteworthy that the relationship between YHWH and the Israelites was covenant based. It is against this backdrop that for the covenant people there was a direct link between sickness and ritual impurity. In most cases in the Old Testament tradition, a direct link is made between offenses and sickness (2 Kings 5). According to Deuteronomy (28: 15-20), sickness is connected to disobedience (Kinsley 1994). It is imperative for one to bear in mind that forgiveness is appropriate and effective in the case where the illness is caused by sins. It follows that if people believed that afflictions could result from sin, forgiveness was a necessity for healing. This tradition is even exposed in the New Testament, for example, in the Gospel of John 9: 2, the following question is posed. His disciples asked him, 'Rabbi, who sinned, this man or his parents, 
that he was born blind?' In a cultural system where sickness is expected to result from sin, absolution of forgiveness will be effective in bringing relief. The normal prescription for forgiveness includes a sacrifice for rectifying the disturbed relationship

\section{Prayers for Healing}

The Old Testament gives the impression that healing was meted out to certain individuals through prayer. The Old Testament makes it clear that God wants to accommodate the needs of humanity. Reference can be made to King Hezekiah who 'became ill and was at the point of death' (2 Kings 20: 1). He consulted with the prophet who bluntly told him, 'Put your house in order, because you are going to die, you will not recover'. In spite of that damning diagnosis, Hezekiah prayed for healing, 'Remember, O, Lord how I have walked before you faithfully and with whole-hearted devotion and have done good in your eyes' (2 Kings 20: 3). The answer was almost instantaneous, as Isaiah promptly returned with good news from God that Hezekiah will be healed and fifteen more years be added to his life.

\section{Methods of Healing in Pentecostalism Considering Chronic Illnesses}

\section{Causes of Sickness in Pentecostalism Today}

In Pentecostalism today, one could find Daneel's (1987) postulation satisfactory that healing prophecy and exorcism have been the major attraction to African Independent Churches (AICs). Although AICs and Pentecostal cannot be loosely referred to as synonyms, it cannot be ignored that most Pentecostals in Zimbabwe, like Zimbabwe Assemblies of God Africa, United Family International Church (UFIC) and Prophetic Healing and Deliverance (PHD) Ministries, also fall in the same bracket of AICs. It is not surprising to note that these churches, in terms of their understanding of the cause of illness, draw much from African spirituality. In separate works, Biri (2012) and Taringa (2013) show how much Pentecostals have borrowed from African Traditional Religion as far as the conception of illness is concerned. This explains the nexus between Pentecostalism and African Traditional religion in terms of understanding illness. Thus, Pentecostalism has become the haven of belonging for African Christians. 


\section{Witches and Sorcerers}

Witchcraft and sorcery as cause of illness in Pentecostalism are closely related, since both are associated with the harm brought about through envy or malice by fellow human beings. The former involves the manipulation of psychic powers, usually through the medium of mystical powers. Witches in African culture are usually female. Anyone can be a witch, and the terrible thing is that they normally harm the nearest and the dearest. In other words, they are the unknown enemy within the gate (Kigunyi 2007).

It is alleged that witches make use of different agents. Some use a variety of animals such as a wolf; a human being who acquire the body of a wolf (due to shape shifting) that do their work. Common animals are hyenas, snakes, baboons and owls. Scholars are not in unison whether these animals are real, or whether they are a mirage. Also, mystical agents such as zvidhoma and zvishiri are seen as the assistants of witches. The tokoloshi is believed to be a little man with only one buttock and a huge penis which he carries over his shoulders or wraps around his waist. Chidhoma are those spirits of children who were killed and are now used by witches as messengers to kill or perform killing duties on their behalf, and these are believed to be merciless. Usually the witch who is angry inflicts the disease directly upon the victim, either through willpower or rituals, or through charms.

\section{Sorcerers}

A sorcerer is one of the most feared types of witches, who can perform his/her acts during daylight. This type of witch can make use of manipulation of lightning or poisoning and is the most feared, unlike the witch who devours human flesh from the graves and walks at night. The sorcerer is known for using chipotsa (object intrusion) which is invasion of a person by a foreign object. This object is often understood to have been shot into the victim by an enemy or a hostile spirit. The object then makes a person ill or kills the person if not removed. Sorcery in Zimbabwe manifests itself through the ability to shoot other people with objects. The objects also may be buried in the path of the one they intend to harm, or remote control can be used by casting spells on the person calling his/her name.

\section{Devil and Evil Spirits}

In the Pentecostal movements today, some illnesses are believed to be caused 
by forces or spirits opposed to God. The devil and malevolent spirits are believed to cause illness out of sheer perverseness or to thwart the divine plan for humankind. Some of these spirits go to the extent of possessing an individual. The possession or invasion by an alien spirit, leads to uncontrollable or violent behaviour. This kind of sickness is attributed to draconian and inimical hostile malevolent forces, the sick person is often viewed (or understands him/herself) as a hapless, innocent victim. Healing involves mustering divine powers to resist a demonic invasion or to defeat malevolent forces.

\section{Healing Methods in Pentecostalism}

Faith healing is the overarching method of healing in the Pentecostal tradition. Loosely defined, 'faith' refers to trust or confidence that the prophet can heal. In this regard, the power of faith has a positive attitude or supportive companionship in healing is the one side of the mind-body, which says that the mind can affect the body positively and negatively. Stated more appropriately, the body and the mind are not two separate entities, but form a unity as mindbody. The one side of the coin can be demonstrated by the placebo effect. The placebo effect refers to the phenomenon that an inert substance or practice has a general effect. In other words, a drug can have an effect on a person because of the belief or the meaning attached to it and not because of its pharmacology. From the above view, it is too early to conclude that faith heals and that in an extreme case faith can kill. Belief in the ability of a healer has been one of the hallmarks of healing practitioners in the $21^{\text {st }}$ century. Therefore, there is nothing sinister stating that a prophet can heal because believers put their trust in their ability and power to heal.

\section{Touching or Laying of Hands}

Contact with a sick person, especially through the hands, is very common in Pentecostalism. This resonates with the understanding replete in the ancient healing stories attributed to Apollonius. In the Greco-Roman world, the implicit assumption of touching or laying of hands was the widespread idea that power resides in individuals and objects.

\section{Some Critical Reflections}

Pentecostal churches' emphasis on the aspect of healing has been a major point 
of attraction for membership. This emanates from the fact that believers have come to categorise sickness in into two groups. In this regard, Mwandayi (2013) is correct when he argues that there are those illnesses which people view as normal, like coughs, slight headaches, fevers or stomach aches, and then there are those sicknesses that are chronic by nature. As Mwandayi (2013) notes, people have no problem requesting conventional medicine for the former, but when it comes to the latter, people consult a traditional healer or a faith healer. Faith healers are consulted because the understanding is that there are certain illnesses that require one to be delivered from the dark world. This article does not intend to dispute Mwandayi's observation. However, it proceeds to add that most believers in Pentecostals today now seek the assistance of faith healers for all types of illnesses. The understanding is that the name of Jesus has the power to heal. Everything that has a name is said to be under the name of Jesus. It follows that since illnesses have a name, they are also cured by the name of Jesus.

In the Pentecostal movement today, there are multifarious testimonies of people who have been healed from a variety of diseases, including HIV and AIDS, diabetes and cancer, among others. In one of his articles, Allen Anderson (2002) gives a testimony of how he and his wife were healed in separate incidents by faith healers. This is synonymous to what is happening in Pentecostals today. One of the women interviewed in this article narrated how she was healed by Prophet John Moyounotsva. He is among the leading figures in Zimbabwe Assemblies of God Africa ${ }^{3}$ and the Resident Father at Bindura Cathedral Prayer Mountains. This is one of the sacred sites in ZAOGA built at a place that is believed to be among the areas where the founder of ZAOGA, Ezekiel Guti, met God. The site is also near the gum tree where ZAOGA ministry started. Prophet Moyounotsva is renowned for holding monthly services where people get cured of various diseases. These services are called Nights of Miracles and they attract people from various walks of life in Zimbabwe and even abroad.

Although there is evidence of healing in the Pentecostal tradition, this concept has been subject to criticism. This stems from some of the alleged strange methods of healing like anointing oil and wrist bands. For instance, believers in Prophecy Healing and Deliverance (PHD) ministries are given

${ }^{3}$ ZAOGA is an African Independent Church in Zimbabwe with Pentecostal traits and it was established in the 1960s by apostle Ezekiel Guti. 
anointing oil and wrist bands at a fee as methods of cure ${ }^{4}$. In defence of the use of anointing oil, believers in PHD quote scriptures like James 5: 14, which says, 'Is anyone among you sick? Let him call for the elders of the church, and let them pray over him, anointing him with oil in the name of the Lord'.

Another informant argues that the execution of faith healing in Pentecostalism leaves a lot to be desired. What is mindboggling and baffling is that they only want to cure people in crusades and church services; yet some people are critically ill in hospitals. Discussions have revealed that whilst it cannot be denied that some faith healers are genuine, most of these miracles are stage managed. One informant narrates how he had witnessed a man being lifted from a wheelchair in what appeared to be a miracle. He was shocked to see the same man again being lifted from the wheelchair at another crusade. This sheds light on the notion that some miracles are performed to hoodwink the people into believing the prophetic power. Some people are even paid to give fake testimonies of healing. Those who would not have met the prophet before also end up giving fake testimonies, because they would have been psychologically conditioned to believe that if they confess that they have not been healed they indicate that God is not able. Consequently, not wanting to belittle God, some people end up giving false testimonies. Where there is failure evident to the congregant that healing has not taken place, the blame is shifted to the victim, namely that he or she did not have enough faith.

A critical mind would therefore want to question why people would still go to these fraudsters in Pentecostal churches today, given that most of them are nothing than mere money-making charlatans. What has been observed is that there is a mind game which is buttressed by indoctrination. This is succinctly captured in a criticism of prophetic following circulating on WhatsApp, namely that it is a mammoth task to advise the follower of a prophet. When uncritical believers see the Men of God their mental faculties subside. This explains why there are increasing numbers of people who have been duped by the so-called men of God. Perhaps this might have been buttressed by the deification of faith healers. Thus, Gunda cogently argues that,

the man of God is a specially set aside individual who is essentially a

${ }^{4}$ PHD is a Pentecostal church in Zimbabwe established by Prophet Walter Magaya and from the name of the church itself, prophecy, healing and deliverance are salient features of this establishment. 
manifestation of the divine hence protected by the divine and in instances where the divine is not respected, the divine reserves the right to avenge (Gunda \& Machingura 2013).

Some believers have died in search of faith healing, especially those suffering from HIV and AIDS. The reason could have been the effect of sensational healing or hypnosis. Some people living with HIV and AIDS were told to stop their anti-retroviral medication after the exercise of faith healing. One informant poignantly narrates the story of her sister who died after she had stopped taking medication. He has this to say, 'My sister died after the prophet instructed her to stop taking medication. Taking drugs was regarded as lack of faith. It's so sad how my sister was gullible to believe the prophet'. What happened was that when his sister stopped taking medication her situation deteriorated but, in a bid to honour the prophet, she would not take medication. When she finally agreed to take the medication, the situation was out of control, leading to her death. This is one among the cases where the prophets' interventions have ostensibly led to the death of gullible believers. Faith healing has seen most members of the Pentecostal movement refraining from taking scientific medication.

\section{The Way Forward}

Faith healing, while it has managed to ameliorate the health of some people, should not be romanticised without further interrogation. Whilst it is true that some illnesses defy scientific explanation and would be better combated through faith healing, there is a danger of spiritualising all illnesses. What faith healers fail to recognise is that it is medical experts who diagnose their believers' illnesses like HIV and AIDS, cancer and diabetes etc. It means that after the diseases have been cured, they should be referred back to medical experts to be declared clear of their infirmities. This means that there is need for a nexus between scientific healing and faith healing. In Zimbabwe, there has been the rude awakening that faith healing is not the ultimate cure. This explains why ZAOGA has erected Mbuya Dorcas Hospital with both a medical wing and a spiritual wing. This is an attempt to deal with the two categories of illnesses, natural and spiritual. Similarly, Prophet Walter Magaya's controversial discovery of aguma is clear testimony that not every disease needs faith healing. Magaya has been renowned for faith healing, but he found it manda- 
tory to find a scientific cure. The merits of $a g u m a^{5}$ are not what is interesting here; rather, the realisation that scientific methods of cure are also a necessity. Thus, faith healing was born out of necessity, like the woman with the flow of blood in the New Testament. She went to Jesus after medical practitioners of her time, had failed her.

\section{Conclusion}

The article has observed that the understanding of sickness and cure in Pentecostalism today is somewhat divorced from the Old Testament Tradition. This is probably because in the Old Testament the divine was the architect of healing through human agents. However, in Pentecostalism this is the work of some shrewd, self-acclaimed faith healers who survive on the gullible behaviour of believers. There are, however, some clergy who have genuinely performed cures. Nonetheless, it cannot be espoused that faith healing be regarded as a sine qua non, since many people have died whose lives could have been saved, had they accessed proper medical treatment. Thus, the article notes with regret that if faith healing is executed uncritically it can spell disaster.

\section{References}

Anderson, A. 2002. Pentecostal Approaches to Faith and Healing. International Review of Mission 91,363: 523 - 534. https://doi.org/10.1111/j.1758-6631.2002.tb00365.x

Biri, K. 2012. The Silent Echoing Voice: Aspects of Zimbabwean Pentecostalism and the Quest for Power, Healing and Miracles. Studia Historiae Ecclesiasticae 33: 37-55.

Daneel, M.L. 1987. Quest for Belonging: Introduction to a Study of African Independent Churches. Gweru: Mambo Press.

Freilich, A.R.1982. Tzaraat Biblical Leprosy. Available at:

https://www.ncbi.nlm.nih.gov>pubmed

${ }^{5}$ Aguma is a drug that Prophet Walter Magaya purports to have discovered as cure for HIV and AIDS, but some critical voices say that the mixture used to make the drug contains anti-retroviral drugs. 
(Accessed on 20 August 2018).

https://doi.org/10.1016/S0190-9622(82)70010-6

Garbinni, G. 1988. History and Ideology in Ancient Israel. Bowden, J. (transl.).

New York: Crossroad.

Gunda, M.R. \& F. Machingura 2013. 'The 'Man of God': Understanding

Biblical Influence on Contemporary Mega-Church Prophets in

Zimbabwe. In Kügler, J., E. Chitando \& M.R. Gunda (eds.): Prophets,

Profits and the Bible in Zimbabwe. Bamberg: Bamberg University Press.

Hayes, C. 2002. Gentile Impurities and Jewish Identities: Intermarriage

Conversion from the Bible to the Talmud. New York. Oxford University

Press. https://doi.org/10.1093/0195151208.001.0001

Hayes, J.H. \& C.R. Holladay 2007. Biblical Exegesis: A Beginner's Handbook.

Atlanta: John Knox Press.

Kigunyi, E.L. 2007. The Problem of Witchcraft. Term Paper. Machakos:

Kenya Scott Theological College.

Kinsley, D. 1994. Health, Healing and Religion: A Cross-cultural Perspective.

New Jersey: Prentice Hall.

Klawans, J. 2000. Impurity and Sin in Ancient Judaism. London: Oxford

University Press.

https://doi.org/10.1093/acprof:oso/9780195132908.001.0001

Mapuranga, T., E. Chitando \& M.R. Gunda 2013. Studying the United Family

International Church in Zimbabwe: The Case for Applying Multiple

Approaches to the Study of Religion and Religious Phenomena. In Kügler

J., E. Chitando \& M.R. Gunda (eds.): Prophets, Profits and the Bible in

Zimbabwe. Bamberg: Bamberg University Press.

Milgrom, J. 2004. Leviticus: A Handbook of Ritual and Ethics. Minneapolis:

Fortress Press.

https://doi.org/10.2307/j.ctv1hqdhw1

Mwandayi, C. 2013. Traversing the Thin Line between 'Chibhoyi' (Indigenous

Spirituality) and Miracle Working. In Kügler, J., E. Chitando \& M.R.

Gunda (eds.): Prophets, Profits and the Bible in Zimbabwe. Bamberg:

Bamberg University Press.

Pummer, R. 1975. Recent Publications on the Methodology of the Science of

Religion. Numen 22.3: 161-182.

https://doi.org/10.1163/156852775X00013

Sacks, J. 2000. The Persistence of Faith: Religion, Morality and Society in a Secular Age. New York: Continuum. 
Taringa, N. 2013. 'For with God nothing is impossible': Reflections on African Initiated Churches (AICs), and Prophets as African Traditional Religions (ATRs) Fundamentalists. In Kügler J., E. Chitando \& M.R. Gunda (eds.): Prophets, Profits and the Bible in Zimbabwe. Bamberg: Bamberg University Press.

Vess, M., J. Arndt, C.R. Cox, C. Routledge \& J.L. Goldenberg 2009. Exploring the Existential Function of Religion: The Effects of Religious Fundamentalism and Morality Science on Faith Based Medical Refusals. Journal of Personality and Social Psychology 197, 2: 334-350. https://doi.org/10.1037/a0015545

Fairchild Siyawamwaya Zimbabwe Ezekiel Guti University (ZEGU) Department of Humanities, Education and Social Sciences fsiyawamwaya@zegu.ac.zw; mambosiya@gmail.com 